\title{
Growth and flowering inhibition of Paspalum notatum with application of trinexapac-ethyl and prohexadione-calcium
}

\author{
Sidnei R. de Marchi ${ }^{1}$, Dagoberto Martins ${ }^{2}$ \& Neumárcio V. Costa ${ }^{3}$ \\ ${ }^{1}$ Universidade Federal de Mato Grosso/Campus Universitário do Araguaia. Barra do Garças, MT. E-mail: sidneimarchi.ufmt@gmail.com (Corresponding author) \\ ${ }^{2}$ Universidade Estadual Paulista/Faculdade de Ciência Agrárias e Veterinárias/Departamento de Fitotecnia. Jaboticabal, SP. E-mail: dmartins@fcav.unesp.br \\ ${ }^{3}$ Universidade Estadual do Oeste do Paraná/Centro de Ciências Agrárias. Marechal Cândido Rondon, PR. E-mail: neumarciovc@hotmail.com
}

\section{Key words:}

Bahiagrass

growth inhibitors

sequential application

\begin{abstract}
A B S T R A C T
This study aimed to evaluate the effect of sequential applications of plant regulators on growth and seedhead emergence of Bahiagrass (Paspalum notatum). The study was carried out on a 15-month-old lawn, in a randomized block design, with four replicates. The treatments consisted of the following plant-growth regulators and dose: trinexapacethyl in sequential application of $113+113,226+113,226+226,452+113,452+226$, $452+452 \mathrm{~g}$ a.i. ha ${ }^{-1}$; trinexapac-ethyl in single application of 678 and $904 \mathrm{~g}$ a.i. $\mathrm{ha}^{-1}$; and prohexadione-calcium in sequential application of $100+100$ and $200+200 \mathrm{~g}$ a.i. $\mathrm{ha}^{-1}$, besides a control, with no application. The effects of treatments were evaluated based on visual injury, plant height, height and number of flower rachises and total dry matter production of clippings. Sequential applications of prohexadione-calcium at $100+100$ or $200+200 \mathrm{~g}$ a.i. ha ${ }^{-1}$ were efficient to reduce plant height, but did not show efficacy to reduce the number and height of seedheads or the total dry matter of clippings of Bahiagrass. However, Bahiagrass lawns can be managed by trinexapac-ethyl sequential applications of $452+452 \mathrm{~g}$ a.i. $\mathrm{ha}^{-1}$ or single application of $904 \mathrm{~g}$ a.i. ha ${ }^{-1}$, with reduction in the need for mowing for a period of up to 113 days after application, without causing any deleterious effect on the visual aspect of the lawn.
\end{abstract}

Palavras-chave: grama-batatais inibidores vegetais aplicação sequencial

\section{Redução do crescimento e do florescimento de Paspalum notatum com aplicações de trinexapac-ethyl ou prohexadione-calcium}

\section{R E S U M O}

Este trabalho teve o propósito de avaliar o efeito da aplicação sequencial de reguladores vegetais sobre o crescimento e a emissão de hastes florais da grama-batatais (Paspalum notatum). O estudo foi instalado em um gramado com 15 meses, no delineamento de blocos casualizados, com quatro repetições; utilizaram-se os seguintes inibidores de desenvolvimento vegetativo: trinexapac-ethyl em aplicações sequenciais de $113+113,226$ $+113,226+226,452+113,452+226$ e $452+452 \mathrm{~g}^{1 a}$ ha $^{-1}$, trinexapac-ethyl em aplicação única a 678 e $904 \mathrm{~g}^{\text {ia ha }} \mathrm{ha}^{-1}$ prohexadione-calcium em aplicações sequenciais nas doses de $100+100$ e $200+200 \mathrm{~g}^{1}$ h ha ${ }^{-1}$, além de um controle sem aplicação dos produtos. O efeito dos tratamentos foi avaliado quanto à injúria visual, altura de plantas, altura e emissão de hastes florais e produção de matéria seca de aparas. As aplicações sequenciais de prohexadionecalcium, independente da dose testada, foram efetivas na redução da altura de plantas mas não apresentaram eficiência na redução do número e altura de inflorescências nem na quantidade total de matéria seca produzida pela grama-batatais; entretanto, gramados formados com a grama-batatais podem ser manejados com o trinexapac-ethyl em aplicação sequencial de $452+452 \mathrm{~g} \mathrm{ha}^{-1}$ ou em aplicação única na dose de $904 \mathrm{~g} \mathrm{ha}^{-1}$, com a redução da necessidade de cortes por um período de até 113 dias após a aplicação sem que ocorra efeito deletério no aspecto visual sobre o gramado. 


\section{INTRODUCTION}

Bahiagrass, 'Forquilha' grass, 'São Sebastião' grass, 'Pensacola' grass and 'Cuiabano' grass are some of the common names by which the species Paspalum notatum Flügge is regionally known. However, the most used term to refer to this Poeaceae in Brazil is Bahiagrass. It originated in South America, where native populations are widely distributed from Mexico to Argentina (Espinoza et al., 2006).

The good establishment and persistence of this species, even under conditions of low fertility, drought or waterlogged soil, guarantee its use for various purposes, such as animal feed, hay production, sport fields, parks and gardens (Krueger \& Adesogan, 2008). However, the most frequent use of this species is in the formation of lawn for protection and control of erosion in areas with exposed soils, after the end of civil construction, such as the sides of slopes, terraces of sheds, roadsides or highway medians and hydroelectric dams, besides areas with sharp declivity (Stibinger, 2011; Li et al., 2011; Coan et al., 2012; Lu, 2014).

One of the advantages of using Bahiagrass is the formation of a dense carpet-like lawns, through the interweaving of stolons, which penetrate and easily root. In spite of that, its vigorous growth brings the disadvantage of requiring constant mowing operations in order to maintain height uniformity and visual quality of the lawn. Usually, 5 to 7 mowing operations are necessary during the growth season, which must be performed at the mean height of $5.0 \mathrm{~cm}$ from the soil surface (Hirata \& Pakiding, 2003; Islan \& Hirata, 2005; Bao \& Hirata, 2006). The best visual quality and covering pattern of the lawn are obtained when mowing, for Bahiagrass, is performed every four days at a mean height of $3.0 \mathrm{~cm}$ (Hirata \& Pakiding, 2003). However, successive mowing operations, especially between the months of spring and summer, are the main source of costs in maintaining lawns, which, associated with the amount of clippings and the tiring activities of piling, carrying and transporting the clippings, have become the main factor of rejection to the use of the technique (Marchi et al., 2013b).

The delay in mowing favors the accumulation of dead material below plant canopy, known as thatch or 'mattress', which hampers the visual quality, for causing straw-yellow color to the lawn immediately after mowing - a phenomenon known as "burned aspect" (McCullough et al., 2007; KojoroskiSilva et al., 2011).

Another factor that affects the visual aspect of the lawn is the intense emergence of flower rachises, especially in lawns formed by $P$. notatum in which the color of the inflorescence is different from the color of the leaves. Furthermore, both leaves and flower rachises can reach excessive heights, which harm the visualization of traffic signs in public roads (Gannon \& Yelverton, 2011).

Therefore, both the costs of successive mowings and the visual aspect lead to the search for alternatives for the mechanical management, such as the use of plant-growth regulators. The utilization of growth regulators is a common practice in the management of various species of grass in the United States, especially the Type-I regulators, i.e., celldivision inhibitors, such as mefluidide and maleic hydrazide, and Type-II regulators, i.e., cell-elongation inhibitors, such as trinexapac-ethyl, prohexadione-calcium and paclobutrazol (Ervin \& Zhang, 2007). Specifically, Type-II regulators are compounds capable of modifying the concentration of hormones in the plants and promoting slight expansions in leaf area and in the development of lateral structures, without the undesirable increases in vertical growth of the grasses (Marchi et al., 2013b). However, growth regulators may cause some undesirable effects when are not properly used. Visual injuries are frequently reported, with consequent alteration in the visual quality of the lawn. Leaf injuries vary depending on the environmental conditions; dark green-toned spots appear in temperate climate regions or discoloration, characterized by the yellowing of leaves, occurs in tropical climate regions (McCarty et al., 2011).

In general, single applications at low doses promote lower levels of injuries associated with short periods of control of height growth and reduction in inflorescence emergence. On the other hand, high doses promote the best results for longer periods, but with high levels of injuries. Such imbalance between efficiency and injury can be solved with sequential applications involving better-adjusted doses (Waltz Jr. \& Whitwell, 2005; Ervin \& Zhang, 2007; McCullough et al., 2007).

Therefore, this study aimed to verify the effect of sequential application of different doses of the growth regulators trinexapac-ethyl and prohexadione-calcium on Bahiagrass growth and flowering.

\section{Material AND Methods}

The study was conducted in an experimental area located at the geographic coordinates of $22^{\circ} 07^{\prime} 56^{\prime \prime} \mathrm{S}$ and $74^{\circ} 66^{\prime}$ $84^{\prime \prime} \mathrm{W}$, at an altitude of $760 \mathrm{~m}$. The lawn, with approximately 15 months, was formed using carpets of Bahiagrass in area irrigated by sprinklers. The soil in the area was classified as typical dystroferric Red Nitosol with moderate A horizon (EMBRAPA, 2006) and clayey texture. After the application of $2.6 \mathrm{t} \mathrm{ha}^{-1}$ of limestone, its chemical analysis showed the following characteristics (Table 1):

During its formation, the lawn was maintained at mean height of $3.0 \mathrm{~cm}$ from the soil through successive mowing operations with a motorized mechanical mower, with rotating cutting blade and a special device for the collection of clippings.

The treatments shown in Table 2 were arranged in a randomized block design, with four replicates, and each plot was $1.5 \mathrm{~m}$ wide and $2.5 \mathrm{~m}$ long, totaling an area of $3.75 \mathrm{~m}^{2}$. Besides the control plot, a 0.5 -m-wide strip was maintained as a lateral control along the experimental blocks, in order to better visualize the possible injuries caused by the growth regulators.

Table 1. Chemical attributes for chemical characterization of the soil in the experimental area in the layer of 0-20 $\mathrm{cm}$

\begin{tabular}{|c|c|c|c|c|c|c|c|c|c|c|}
\hline \multirow{2}{*}{$\begin{array}{c}\mathrm{pH}-\mathrm{CaCl}_{2} \\
\left(0.01 \mathrm{~mol} \mathrm{~L}^{-1}\right)\end{array}$} & \multirow{2}{*}{$\begin{array}{c}O C \\
\left(g^{\left.~ ~ k g^{-1}\right)}\right.\end{array}$} & \multirow{2}{*}{$\begin{array}{c}\mathbf{P} \\
\left(\mathrm{mg} \mathrm{kg}^{-1}\right)\end{array}$} & $\mathrm{Ca}$ & $\mathrm{Mg}$ & K & Al & $\mathrm{H}+\mathrm{Al}$ & CEC & \multirow{2}{*}{$\begin{array}{l}V \\
(\%)\end{array}$} & \multirow{2}{*}{$\begin{array}{c}\mathrm{Fe}_{2} \mathrm{O}_{3} \\
\left(\mathrm{~g} \mathrm{~kg}^{-1}\right)\end{array}$} \\
\hline & & & \multicolumn{6}{|c|}{$\left(\mathrm{mmol}_{\mathrm{c}} \mathrm{kg}^{-1}\right)$} & & \\
\hline 5.9 & 15 & 12 & 27 & 13 & 9.6 & 0.3 & 32.9 & 82.9 & 60 & 176 \\
\hline
\end{tabular}

OC - Organic carbon; CEC - Cation exchange capacity; $\vee$ - Base saturation 
Table 2. Growth regulators and doses used in the first and second application on Paspalum notatum

\begin{tabular}{lccc}
\hline \multirow{2}{*}{ Treatments } & \multicolumn{3}{c}{ Doses $\left(\mathbf{g}\right.$ a.i. ha $\mathbf{~}^{-1}$ ) } \\
\cline { 2 - 4 } Trinexapac-ethyl & $\mathbf{1 0}^{\mathbf{0}}$ Application & $\mathbf{2}^{\mathbf{0}}$ Application ${ }^{1}$ & Total \\
\hline Trinexapac-ethyl & 113 & 113 & 226 \\
\hline Trinexapac-ethyl & 226 & 113 & 339 \\
\hline Trinexapac-ethyl & 226 & 226 & 452 \\
\hline Trinexapac-ethyl & 452 & 113 & 565 \\
Trinexapac-ethyl & 452 & 226 & 678 \\
\hline Trinexapac-ethyl & 452 & 452 & 904 \\
Trinexapac-ethyl & 678 & 0 & 678 \\
\hline Prohexadione-calcium & 904 & 0 & 904 \\
Prohexadione-calcium & 100 & 100 & 200 \\
Control & 200 & 200 & 400 \\
\hline
\end{tabular}

${ }^{1}$ Second application was performed when the mean height of plants in the treated area reached $70 \%$ in relation to the mean height of plants in the control

The applications were performed using a $\mathrm{CO}_{2}$-pressurized backpack sprayer, attached to a spraying bar containing two flat jet nozzles (TP $80.02 \mathrm{VS}$ ) spaced by 50 and $50 \mathrm{~cm}$ distant from the mean height of plants. The entire set was maintained at constant pressure of $2.0 \mathrm{bar}$, in order to promote a consumption of solution equivalent to $200 \mathrm{~L} \mathrm{ha}^{-1}$.

The first application was performed in late November, with partially clouded sky, air temperature of $26.3^{\circ} \mathrm{C}$, relative humidity of $69 \%$ and wind gusts at $9.0 \mathrm{~km} \mathrm{~h}^{-1}$ in the SE direction. During application, the plots were laterally protected with screens of plastic canvas in order to avoid the drift of the sprayed solution to the surrounding plots. The study was conducted from November to early May.

The sequential dose of inhibitors was initially planned to be used always when the mean height of certain treatment reached the equivalent to $70 \%$ of the mean height in the control, regardless of the days elapsed after the previous application. Then, the lawn was mowed again at approximately $3.0 \mathrm{~cm}$. After that, the second dose of growth regulators was applied.

The clippings were collected after each mowing, placed in paper bags and maintained in a forced-air oven at $65^{\circ} \mathrm{C}$, until reaching constant mass, for the determination of dry matter.

The evaluations of injury and growth reduction were weekly performed until mid-April, a period in which both the control and the treated areas no longer showed alterations in height as a function of the decrease in temperature and duration of the light period of the day, which are phenomena characteristic of the autumn season for the Southeast region, where the study was conducted.

The injuries caused by the treatments were visually evaluated using the scale from 0 to $100 \%$, in which $0 \%$ represents absence of injury and $100 \%$ represents the death of the plants. Growth reduction was evaluated through the direct measurement of plant height using a $\mathrm{cm}$-graduated ruler. The number and height of emerged inflorescences were evaluated through a sampling, performed in an area of $0.25 \mathrm{~m}^{2}$ in the center of the plots before cutting the lawn for the reapplication and at the end of the experimental period, for the determination of total dry matter of clippings (TDMC), represented by the sum of the dry matter from all the mowing operations.

After obtaining plant height, number of inflorescences and total dry matter of clippings, it was possible to calculate the percentage of reduction of the respective variable using the equation $\mathrm{R}(\%)=\left[\left(\mathrm{V}_{\mathrm{es}}-\mathrm{V}_{\mathrm{rt}}\right) \times 100\right] / \mathrm{V}_{\mathrm{es}}$, in which $\mathrm{R}$ is the reduction of the variable, $\mathrm{V}_{\mathrm{es}}$ is the value of the variable obtained in the control and $V_{r t}$ is the value of the variable obtained in the respective treatment, expressed in percentage.

The obtained results were subjected to the analysis of variance by $\mathrm{F}$ test and, if significant, the means were compared by Tukey test at 0.05 probability level.

\section{Results AND Discussion}

In general, the dose of trinexapac-ethyl and prohexadionecalcium did not promote satisfactory control of Bahiagrass growth, since plant height in almost all the treatments reached the mowing limit already seven days after the first application (DAFA) (Figure 1A). The only exception is the highest doses of trinexapac-ethyl (904 $\mathrm{g}$ a.i. ha $\mathrm{a}^{-1}$ ), which inhibited Bahiagrass growth in both evaluation periods (Figures $1 \mathrm{~A}$ and $1 \mathrm{~B}$ ).

Thus, it was decided not to perform the mowing, but apply the second dose in all the treatments in order to verify whether any effect of treatment would occur on plant height. However, this effect could not be observed in the evaluation at 14 DAFA (Figure 1B), since only the highest dose trinexapac-ethyl (904 $\mathrm{g}$ a.i. ha ${ }^{-1}$ ) continued conditioning plant height below the limit mowing line.

The recovery in height growth is a common event for most tropical climate grasses, because non-structural carbohydrates such as glucose, fructose, sucrose and amides can be stored and used as reserve energy for tolerance to stress, recovery of dormancy and regrowth after the removal of shoots (Waltz Jr. \& Whitwell, 2005). In this study, the fast recovery of height development was initially due to the redistribution of nonstructural carbohydrates that were stored in the stolons and

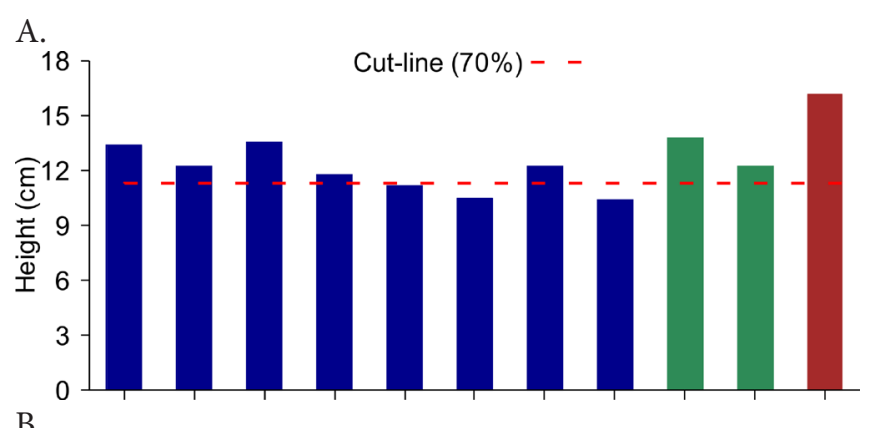

B.

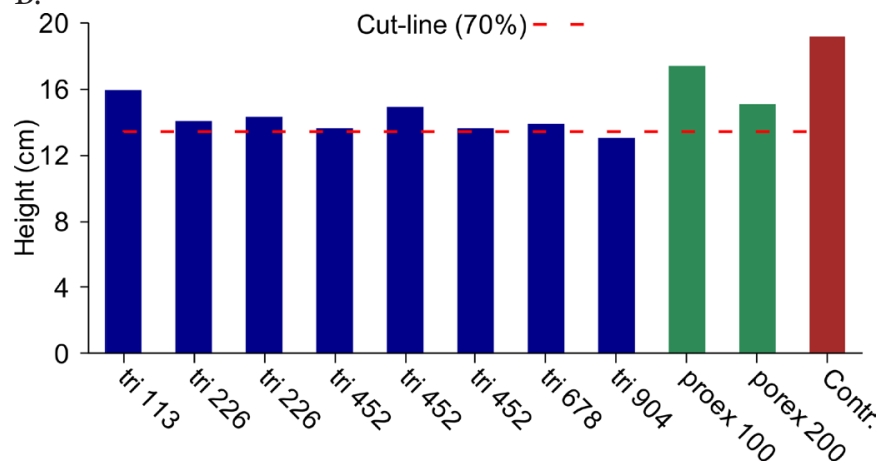

Figure 1. Height of Paspalum notatum at 7 (A) and 14 (B) days after the first application (DAFA) of dose of trinexapac-ethyl and prohexadione-calcium 
rhizomes of the Bahiagrass, immediately after the cutting of leaves for the application of growth regulators (Waltz Jr. \& Whitwell, 2005; Ervin \& Zhang, 2007; McCullough et al., 2007). It should be pointed out that single doses of Type-II growth regulators promote, besides the evident reduction in the concentration of gibberellins, the increase in the total concentration of chlorophyll $b$ in the leaves up to two weeks after application. Thus, leaves become more efficient at capturing light energy and, consequently, there is higher $\mathrm{CO}_{2}$ fixation and production of non-structural carbohydrates (Ervin \& Zhang, 2007).

The highest dose of trinexapac-ethyl ( $904 \mathrm{~g}$ a.i. ha ${ }^{-1}$ ) promoted injuries to Bahiagrass leaves at 7 and 14 days after the second application (DASA), with a yellowing of leaves of approximately 5.5 and $2.5 \%$, respectively, in each evaluation period. However, the levels of injury receded quickly and substantially, with total recovery of lawn color at 21 DASA (Table 3 ).

The utilization of Type-II growth regulators usually causes visual symptoms of phytotoxicity when applied on grasses

Table 3. Injury values observed in Paspalum notatum after the second application of the doses of trinexapac-ethyl and prohexadione-calcium

\begin{tabular}{lccc}
\hline \multirow{2}{*}{$\begin{array}{c}\text { Treatments } \\
\text { (g a.i. ha } \mathbf{~}^{-1} \text { ) }\end{array}$} & \multicolumn{3}{c}{ Days after the second application } \\
\cline { 2 - 5 } & $\mathbf{7}^{\mathbb{1}}$ & $14^{\mathbb{1}}$ & $\mathbf{2 1}$ \\
Trinexapac-ethyl $113+113$ & $1.0(0.0) \mathrm{b}$ & $1.0(0.0) \mathrm{b}$ & 0 \\
Trinexapac-ethyl $226+113$ & $1.0(0.0) \mathrm{b}$ & $1.0(0.0) \mathrm{b}$ & 0 \\
Trinexapac-ethyl $226+226$ & $1.0(0.0) \mathrm{b}$ & $1.0(0.0) \mathrm{b}$ & 0 \\
Trinexapac-ethyl $452+113$ & $1.0(0.0) \mathrm{b}$ & $1.0(0.0) \mathrm{b}$ & 0 \\
Trinexapac-ethyl $452+226$ & $1.0(0.0) \mathrm{b}$ & $1.0(0.0) \mathrm{b}$ & 0 \\
Trinexapac-ethyl $452+452$ & $1.0(0.0) \mathrm{b}$ & $1.0(0.0) \mathrm{b}$ & 0 \\
Trinexapac-ethyl 678 & $1.0(0.0) \mathrm{b}$ & $1.0(0.0) \mathrm{b}$ & 0 \\
Trinexapac-ethyl 904 & $2.2(5.5) \mathrm{a}$ & $1.7(2.5) \mathrm{a}$ & 0 \\
Prohexadione-calcium $100+100$ & $1.0(0.0) \mathrm{b}$ & $1.0(0.0) \mathrm{b}$ & 0 \\
Prohexadione-calcium $200+200$ & $1.0(0.0) \mathrm{b}$ & $1.0(0.0) \mathrm{b}$ & 0 \\
Control & $1.0(0.0) \mathrm{b}$ & $1.0(0.0) \mathrm{b}$ & 0 \\
F Treatment & $2.98^{\star \star}$ & $3.00^{\star \star}$ & - \\
F Block & $1.00^{\mathrm{NS}}$ & $1.00^{\mathrm{NS}}$ & - \\
LSD & 1.06 & 0.62 & - \\
CV (\%) & 38.66 & 23.67 & - \\
\hline
\end{tabular}

NSNot significant; ** Significant at 0.01 probability level; Means followed by the same letter do not differ statistically by Tukey test at 0.05 probability level; ' 1 Means transformed to $\sqrt{ } \mathrm{X}+$ 1.0; Original means between parentheses; LSD - Least significant difference; CV - coefficient of variation
(McCarty et al., 2011), as well as the use of ALS-inhibitor herbicides (McDonald et al., 2006).

The deleterious effects of the injury caused by trinexapacethyl and bispyribac-sodium can be quickly reversed with the use of supplementary source of iron or nitrogen, which play an important role in the formation of chlorophylls, thus returning the green color to the grass leaves (Ervin et al., 2004; McDonald et al., 2006). In the present study, the fast recovery of Bahiagrass is probably related to the high content of available iron in the soil of the experimental area, since the chemical analysis showed $176 \mathrm{~g} \mathrm{~kg}^{-1}$ of iron oxide $-\mathrm{Fe}_{2} \mathrm{O}_{3}$ (Table 1).

The vegetative growth of Bahiagrass was reduced by all the doses and growth regulators used in this study, and the effects on plant height extended to 99 DASA, when the evaluations stopped due to the stabilization in the development of plants in the control treatment, because of the climatic conditions, such as the decrease in temperature and luminosity. It is important to highlight that the total period between the first growth regulator application and the final evaluation was equivalent to 113 days.

Trinexapac-ethyl stood out regarding the action on the development of Bahiagrass, because all the doses used reduced plant height, regardless of the evaluation period. Height reduction was above $45 \%$ in relation to the control, even when the lowest sequential dose of $113+113 \mathrm{~g}$ a.i. ha ${ }^{-1}$ was used (Figure 1).

The sequential application of trinexapac-ethyl $(452+226$ g a.i. ha ${ }^{-1}$ ) reduced the height of Bahiagrass by $72 \%$ and the single dose ( $904 \mathrm{~g}$ a.i. ha ${ }^{-1}$ ) by $85 \%$ at 99 DASA, compared with the plant height in the control (Table 4).

The prohexadione-calcium used in sequential application at the doses of $100+100$ and $200+200 \mathrm{~g}$ a.i. ha ${ }^{-1}$ was also efficient in the reduction of vertical growth of Bahiagrass at 99 DASA, because the mean plant heights were $27.3 \mathrm{~cm}$ and $28.0 \mathrm{~cm}$, respectively, and statistically lower than mean height of the plants, which was also observed in the control (Table 4). It should be highlighted that the reductions caused by the sequential applications of prohexadione-calcium at the doses of $100+100$ and $200+200 \mathrm{~g}$ a.i. ha $^{-1}$ promoted reductions in the vertical height of Bahiagrass of about $38 \%$ at 99 DASA (Table 4).

Table 4. Plant height of Paspalum notatum obtained after the second application of the dose of trinexapac-ethyl and prohexadione-calcium

\begin{tabular}{|c|c|c|c|c|c|c|c|c|}
\hline \multirow{2}{*}{$\begin{array}{l}\text { Treatments } \\
\left(\mathrm{g} \text { a.i. ha } \mathrm{h}^{-1}\right)\end{array}$} & \multicolumn{7}{|c|}{ Days after the second application (DASA) } & \multirow{2}{*}{$\begin{array}{l}R^{\mathbb{1}} \\
(\%)\end{array}$} \\
\hline & 7 & 21 & 28 & 35 & 63 & 85 & 99 & \\
\hline Trinexapac-ethyl $113+113$ & 5.6 cde & $6.9 \mathrm{~b}$ & $7.5 \mathrm{~b}$ & $8.6 \mathrm{~b}$ & $12.9 \mathrm{bc}$ & 15.9 bc & 24.5 bc & 45.6 \\
\hline Trinexapac-ethyl $226+113$ & $5.9 \mathrm{~cd}$ & $6.1 \mathrm{~b}$ & $6.2 \mathrm{~b}$ & $6.4 \mathrm{~b}$ & $8.3 \mathrm{bc}$ & $13.2 \mathrm{bc}$ & $22.9 \mathrm{bcd}$ & 49.1 \\
\hline Trinexapac-ethyl $226+226$ & 4.8 cde & $5.4 \mathrm{~b}$ & $5.8 \mathrm{~b}$ & $6.0 \mathrm{~b}$ & $9.2 \mathrm{bc}$ & $13.7 \mathrm{bc}$ & $20.5 \mathrm{bcd}$ & 54.4 \\
\hline Trinexapac-ethyl $452+113$ & 4.7 cde & $5.1 \mathrm{~b}$ & $5.9 \mathrm{~b}$ & $6.5 b$ & $8.6 \mathrm{bc}$ & $11.3 \mathrm{bc}$ & $18.5 \mathrm{bcd}$ & 58.9 \\
\hline Trinexapac-ethyl $452+226$ & 4.4 cde & $4.5 b$ & $5.4 b$ & $5.7 \mathrm{~b}$ & $11.0 \mathrm{bc}$ & $12.7 \mathrm{bc}$ & 17.9 bcde & 60.2 \\
\hline Trinexapac-ethyl $452+452$ & $3.5 \mathrm{e}$ & $4.1 \mathrm{~b}$ & $5.3 b$ & $5.9 \mathrm{~b}$ & $6.2 \mathrm{c}$ & $7.7 \mathrm{c}$ & $12.6 \mathrm{de}$ & 72.0 \\
\hline Trinexapac-ethyl 678 & $3.7 \mathrm{de}$ & $4.1 \mathrm{~b}$ & $4.6 \mathrm{~b}$ & $6.0 \mathrm{~b}$ & $6.0 \mathrm{c}$ & $7.9 \mathrm{c}$ & 13.6 cde & 69.8 \\
\hline Trinexapac-ethyl 904 & $3.4 \mathrm{e}$ & $3.9 \mathrm{~b}$ & $4.2 \mathrm{~b}$ & $5.4 \mathrm{~b}$ & $5.8 \mathrm{C}$ & $6.3 c$ & $6.9 \mathrm{e}$ & 84.7 \\
\hline Prohexadione-calcium $100+100$ & $6.0 \mathrm{c}$ & $6.5 \mathrm{~b}$ & $7.3 \mathrm{~b}$ & $8.8 \mathrm{~b}$ & $16.4 \mathrm{~b}$ & $18.2 \mathrm{~b}$ & $27.3 \mathrm{~b}$ & 39.3 \\
\hline Prohexadione-calcium $200+200$ & 5.2 cde & $5.4 \mathrm{~b}$ & $6.8 \mathrm{~b}$ & $7.4 \mathrm{~b}$ & $12.6 \mathrm{bc}$ & $19.6 \mathrm{~b}$ & $28.0 \mathrm{~b}$ & 37.8 \\
\hline Control & $20.9 \mathrm{a}$ & $26.1 \mathrm{a}$ & $27.4 \mathrm{a}$ & $29.0 \mathrm{a}$ & $37.5 \mathrm{a}$ & $38.1 \mathrm{a}$ & $45.0 \mathrm{a}$ & - \\
\hline F Treatment & $132.1^{\star \star}$ & $69.6^{\star \star}$ & $89.3^{\star \star}$ & $116.0^{\star \star}$ & $32.9 * \star$ & $19.9 * \star$ & $18.6^{\star \star}$ & - \\
\hline F Block & $5.4^{\star \star}$ & $3.4^{\star}$ & $8.2^{\star \star}$ & $11.8^{\star \star}$ & $6.1^{\star \star}$ & $11.0^{\star *}$ & $15.3^{\star *}$ & - \\
\hline LSD & 2.1 & 3.8 & 3.4 & 3.1 & 7.7 & 9.7 & 11.5 & - \\
\hline CV (\%) & 12.8 & 21.6 & 16.2 & 13.6 & 25.8 & 26.2 & 21.6 & - \\
\hline
\end{tabular}

NsNot significant; ** Significant at 0.01 probability level; *Significant at 0.05 probability level; Means followed by the same letter in the column do not differ statistically by Tukey test at 0.05 probability level; ${ }^{1}$ Height reduction calculated in relation to the control; LSD - Least significant difference; CV - coefficient of variation 
Freitas et al. (2002) studied the effects of trinexapac-ethyl on the growth and flowering of Bahiagrass and observed direct relationship between the increase in the doses of the growth regulator trinexapac-ethyl and the period of control of vegetative growth and flowering, thereby avoiding cuts in the lawn for a period of up to 12 weeks with the application of $0.75 \mathrm{~kg} \mathrm{ha}^{-1}$. Similar reductions in the vertical growth were observed by Costa et al. (2009), who reported reduction of $61 \%$ in the height of Bahiagrass for a period of 70 days, using trinexapac-ethyl in sequential applications at the dose of $113+113 \mathrm{~g}$ a.i. $\mathrm{ha}^{-1}$.

The lowest heights of inflorescences were obtained when trinexapac-ethyl was applied in sequential application of 452 +452 or in single application of $904 \mathrm{~g}$ a.i. $\mathrm{ha}^{-1}$. The mean heights observed were 17.1 and $12.6 \mathrm{~cm}$, respectively, and statistically lower than the mean height of inflorescences (61.3 $\mathrm{cm}$ ) observed in the control. The other treatments, despite also promoting lower inflorescence heights, were statistically similar to the control (Table 5).

The total number of inflorescences was also substantially reduced by most of the doses of the evaluated growth regulators; only prohexadione-calcium at $100+100 \mathrm{~g}^{\text {a.i. }}$ ha $^{-1}$ was not efficient, since it caused number of inflorescences similar to that of the control and reduction of only $16.9 \%$ in the number of flower rachises at 99 DASA (Table 5).

A growth regulator for being commercially acceptable must promote reduction in flower rachis emergence higher than $70 \%$ (Johnson, 1994). In the present study, reductions above $70 \%$ in flower rachis emergence were obtained when trinexapac-ethyl was used in sequential application at $226+113,226+226,452$ $+113,452+226,452+452$ and in single applications at the doses of 678 and $904 \mathrm{~g}$ a.i. ha ${ }^{-1}$. This last cited dose allowed the emergence of only 6.2 inflorescences per square meter, representing a reduction of $94.1 \%$ in the emergence of flower rachises at 99 DASA (Table 5).

Table 5. Height, number of inflorescences, percent reduction in the number of inflorescences (RI), total dry matter of clippings (TDMC) and percent reduction in dry matter of clippings (RM) of Paspalum notatum at 99 days after the second application of the doses of trinexapac-ethyl and prohexadione-calcium

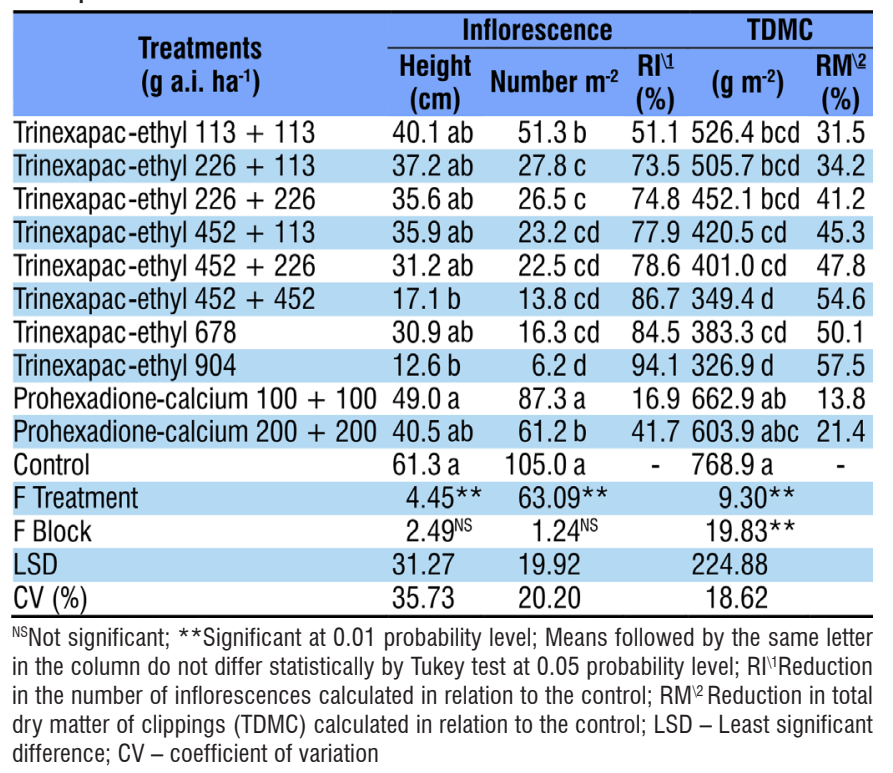

In $P$. notatum, the application of $770 \mathrm{~g}$ a.i. $\mathrm{ha}^{-1}$ of trinexapacethyl in single dose reduced by $74 \%$ the emergence of flower rachises in the period of 77 days (Baker et al., 1999). These researchers also observed that the sequential application of the same dose of the plant growth inhibitor reduced by $91 \%$ the emergence of flower rachises for a period of 84 days after application. Freitas et al. (2002) obtained reduction of 58\% in the number of inflorescences emerged in $P$. notatum for a period of 63 days after application, using trinexapac-ethyl in a single dose of $750 \mathrm{~g}$ a.i. ha ${ }^{-1}$. However, different results were reported by Costa et al. (2009), who observed that the sequential application of trinexapac-ethyl $(113+113 \mathrm{~g}$ a.i. $\mathrm{ha}^{-1}$ ) promoted reduction of only $28.5 \%$ in the emergence of flower rachises of $P$. notatum in the period of 70 days after the second application.

The literature cites that Type-II growth inhibitors used in lawns, such as trinexapac-ethyl and prohexadione-calcium, are not very efficient at avoiding the emergence of flower rachises, because they interfere with the biosynthesis of gibberellins and, consequently, with the reduction of cell elongation (Mittlesteadt et al., 2009). However, Ervin \& Zhang (2007) propose that the great reductions in the emergence of flower rachises observed in the present study are probably due to the physiological alterations caused by high amounts of active ingredient from the high doses or sequential applications of the growth regulators. In addition, it is due to the fact that the experiment was conducted under tropical climate conditions, differing from the studies in the literature, which were mostly conducted under temperate climate.

The total dry matter of clippings (TDMC) of Bahiagrass was reduced by trinexapac-ethyl, because all the studied doses produced amounts of clippings significantly lower than that in the control. The smallest amounts of clippings were obtained when trinexapac-ethyl was applied in sequential dose of $452+452 \mathrm{~g}$ a.i. ha ${ }^{-1}$ and single dose of $904 \mathrm{~g}$ a.i. ha ${ }^{-1}$, respectively representing productions of 349.4 and $326.9 \mathrm{~g}$ $\mathrm{m}^{-2}$ during a period of almost 113 days. It should be pointed out that reductions in TDMC were equal to 54.6 and $57.5 \%$, respectively, in comparison to the control, which can represent the same reduction in the need for mowing in the same period (Table 5).

The productions of TDMC observed when prohexadionecalcium was used in sequential application at $100+100$ and $200+200 \mathrm{~g}$ a.i. ha ${ }^{-1}$ were respectively of 662.9 and $603.9 \mathrm{~g} \mathrm{~m}^{-2}$, statistically similar to the production of $768.9 \mathrm{~g} \mathrm{~m}^{-2}$ obtained in the control (Table 5).

Ferrell et al. (2003), evaluating the sequential application of growth inhibitors in Paspalum vaginatum, observed that trinexapac-ethyl used at the doses of 90 and $380 \mathrm{~g}$ a.i. ha ${ }^{-1}$ promoted reductions of 59 and $96 \%$, respectively, in the vegetative growth of the grass in the period of 70 days after application.

Ervin \& Ok (2001) and Ervin et al. (2002) observed reductions of 35 to $75 \%$ in the amount of clippings produced by the zoysiagrass with the application of trinexapac-ethyl. Costa et al. (2009) used sequential applications of trinexapacethyl at $55.6+55.6$ and $113+113 \mathrm{~g}$ a.i. $\mathrm{ha}^{-1}$, and observed reductions of 49.2 to $55.6 \%$, respectively, in the production of 
dry matter of zoysiagrass. Marchi et al. (2013a) observed that the sequential application of trinexapac-ethyl at the doses of $113+113,226+226,453+226$ and $904+452$ g a.i. ha ${ }^{-1}$, or the sequential application of prohexadione-calcium a $100+100 \mathrm{~g}$ a.i. $\mathrm{ha}^{-1}$ promoted reductions higher than $84 \%$ in dry matter production of zoysiagrass (Zoysia japonica), compared with the production in the control.

Specifically, with respect to Bahiagrass, the only studies found in the literature comment that single applications of trinexapac-ethyl at 750, 1000 and $1250 \mathrm{~g}$ a.i. ha ${ }^{-1}$ reduced by approximately $60 \%$ the amount of clippings produced by $P$. notatum in the period of 49 days after application. However, the sequential application of trinexapac-ethyl at the doses of 56.5 +56.5 or $113+113 \mathrm{~g}$ a.i. ha ${ }^{-1}$ promoted reductions of 48.4 and $68.7 \%$, respectively, in the dry matter production of $P$. notatum 70 days after application (Freitas et al., 2002; Costa et al., 2009).

\section{Conclusions}

1. None of the growth inhibitors reduced the visual quality of Paspalum notatum.

2. Sequential applications of prohexadione-calcium were effective in the reduction of plant height, but did not reduce the number and height of inflorescences or the total dry matter production of Paspalum notatum.

3. The sequential applications of trinexapac-ethyl showed higher efficiency for the reduction of vegetative growth and inflorescence emergence.

4. Trinexapac-ethyl in sequential application of $452+452$ $\mathrm{g} \mathrm{ha}^{-1}$ or in single application of $904 \mathrm{~g} \mathrm{ha}^{-1}$ was more efficient in the reduction of growth and emergence of inflorescences of Paspalum notatum.

\section{Literature Cited}

Baker, R. D.; McCarty, L. B.; Colvin, D. L.; Higgins, J. M.; Weinbrecht, J. S.; Moreno, J. E. Bahiagrass (Paspalum notatum) seedhead suppression following consecutive yearly applications of plant growth retardants. Weed Technology, v.13, p.378-384, 1999.

Bao, G. Z.; Hirata, M. Effects of defoliation frequency on the development and establishment of a vegetatively planted turfgrass Eremochloa ophiuroides (Centipede Grass). Tropical Grasslands, v.40, p.102-110, 2006.

Coan, R. M.; Turco, J. E. P.; Pivetta, K. F. L.; Costa, M. N.; Mateus, C. M. A. Emerald zoyzia grass development regarding photosynthetically active radiation in different slopes. Engenharia Agrícola, v.32, p.501-509, 2012. http://dx.doi. org/10.1590/S0100-69162012000300009

Costa, N. V.; Martins, D.; Rodella, R. A.; Rodrigues, A. C. P.; Cardoso, L. A. Características morfológicas de gramas em resposta a aplicação de trinexapac-ethyl. Planta Daninha, v.27, p.113-122, 2009. http://dx.doi.org/10.1590/S0100-83582009000100015

EMBRAPA - Empresa Brasileira de Pesquisa Agropecuária. Sistema brasileiro de classificação de solos. Brasília: Embrapa Informação Tecnológica, 2006. 306p.

Ervin, E. H.; Ok, C. H. Influence of plant growth regulators on suppression and quality of 'Meyer' Zoysiagrass. Journal of Environmental Horticulture, v.19, p.57-60, 2001.
Ervin, E. H.; Ok, C. H.; Fresenburg, B. S.; Dunn, J. H. Trinexapacethyl restricts shoot growth and prolongs stand density of 'Meyer' zoysiagrass fairway under shade. Hortscience, v.37, p.502-505, 2002.

Ervin, E. H.; Zhang, W. Influence of sequential trinexapac-ethyl applications on cytokinin content in creeping bentgrass, kentucky bluegrass, and hybrid bermudagrass. Crop Science, v.47, p.21452151, 2007. http://dx.doi.org/10.2135/cropsci2007.01.0056

Ervin, E. H.; Zhang, W.; Goatley, J. M.; Askew, S. D. Trinexapac-ethyl, propiconazole, iron and biostimulant effects on shaded creeping bentgrass. HortTechnology, v.14, p.500-506, 2004.

Espinoza, F.; Daurelio, L. D.; Pessino, S. C.; Valle, E. M.; Quarin, C. L. Genetic characterization of Paspalum notatum accessions by AFLP markers. Plant Systematics and Evolution, v.258, p.147-159, 2006. http://dx.doi.org/10.1007/s00606-005-0401-x

Ferrell, J. A.; Murphy, T. R.; Duncan, R. R.; Vencill, W. K. Seashore paspalum response to trinexapac-ethyl and paclobutrazol. Hortsciense, v.38, p.605-606, 2003.

Freitas, F. C. L.; Ferreira, L. R.; Silva, A. A.; Barbosa, J. G.; Miranda, G. V. Efeitos do trinexapac-ethyl sobre o crescimento e florescimento da grama-batatais. Planta Daninha, v.20, p.477-486, 2002. http:// dx.doi.org/10.1590/S0100-83582002000300020

Gannon, T. W.; Yelverton, F. H. Application Placement Equipment for Bahiagrass (Paspalum notatum) Suppression along Roadsides. Weed Technology, v.25, p.77-83, 2011. http://dx.doi.org/10.1614/ WT-D-10-00074.1

Hirata, M.; Pakiding, W. Responses of bahiagrass to nitrogen and defoliation. Journal of Range Management, v.56, p.608-615, 2003. http://dx.doi.org/10.2307/4003935

Islan, M. A.; Hirata, M. Leaf appearance, death and detachment, and tillering in centipedegrass (Eremochloa ophiuroides (Munro) Hack.) in comparison with bahiagrass (Paspalum notatum Flügge): A study at a small sod scale. Grassland Science, v.51, p.121-127, 2005. http://dx.doi.org/10.1111/j.1744-697X.2005.00017.x

Johnson, B. J. Influence of plant growth regulators and mowing on two bermudagrassess. Agronomy Journal, v.86, p.805-810, 1994. http://dx.doi.org/10.2134/agronj1994.00021962008600050011x

Kojoroski-Silva, C. M.; Scheffer-Basso, S. M.; Carneiro, C. M.; Guarienti, M. Desenvolvimento morfológico das gramas Esmeralda, São Carlos e Tifton 419. Ciência e Agrotecnologia, v.35, p.471-477, 2011. http://dx.doi.org/10.1590/S1413-70542011000300005

Krueger, A.; Adesogan, A. T. Effects of different mixtures of fibrolytic enzymes on digestion and fermentation of bahiagrass hay. Animal Feed Science and Technology, v.145, p.84-94, 2008. http://dx.doi. org/10.1016/j.anifeedsci.2007.05.041

Li, X. H.; Zhang, Z.; Yang, J.; Zhang, G.; Wang, B. effects of bahia grass cover and mulch on runoff and sediment yield of sloping red soil in southern China. Pedosphere, v.21, p.238-243, 2011. http://dx.doi.org/10.1016/S1002-0160(11)60123-9

$\mathrm{Lu}, \mathrm{P}$. L. Using multiple vegetation layers to reduce the risk of rainfall-induced landslides and facilitate post-landslide slope rehabilitation. Access International Journal of Agricultural Science, v.2, p.13-17, 2014.

Marchi, S. R.; Martins, D.; Costa, N. V.; Silva, J. R. V. Effect of plant regulators on growth and flowering of "Meyer" Zoysiagrass. Planta Daninha, v.31, p.695-703, 2013a. http://dx.doi. org/10.1590/S0100-83582013000300021

Marchi, S. R.; Martins, D.; McElroy, J. S. Growth inhibitors in turfgrass. Planta Daninha, v.31, p.733-747, 2013b. http://dx.doi.org/10.1590/ S0100-83582013000300025 
McCarty, L. B.; Willis, T. G.; Toler, J. E.; Whitwell, T. 'Ttifeagle' bermudagrass response to plant growth regulators and mowing height. Agronomy Journal, v.103, 988-994, 2011. http://dx.doi. org/10.2134/agronj2010.0467

McCullough, P. E.; Liu, H.; McCarty, L. B.; Toler, J. E. Trinexapac-ethyl application regimens influence growth, quality, and performance of bermuda grass and creeping bentgrass putting greens. Crop Science, v.47, p.2138-2144, 2007.http://dx.doi.org/10.2135/cropsci2006.04.0256

McDonald, S. J.; Dernoeden, P. H.; Kaminski, J. E. Creeping bentgrass tolerance and annual bluegrass control with bispyribac-sodium tank-mixed with iron and nitrogen. Applied Turfgrass Science, v.3, p.1-5, 2006.
Mittlesteadt, T. L.; Goatley, J. M.; Askew, S. D.; Hensler, K. L.; Askew, W. L. Low-impact conversion of cool-season turf to 'patriot' bermudagrass. International Turfgrass Society Research Journal, v.11, p.1205-1212, 2009.

Stibinger, J. Land use, soil conservation and rain harvesting structures on a slope land orchard at Sufen (Taiwan) during of action of typhoon herb - elementary numerical experiment. Agricultura Tropica et Subtropica, v.44, p.22-29, 2011.

Waltz Jr., F. C.; Whitwell, T. Trinexapac-ethyl effects on total nonstructural carbohydrates of field grown hybrid bermudagrass. International Turfgrass Society Research Journal, v.10, p.899-903, 2005. 